\title{
Os convivas da morte no banquete das almas: presença de eguns em um conto de João Antônio \\ Gilberto Figueiredo Martins ${ }^{1}$
}

\begin{abstract}
A morte não é um acontecimento puramente de ordem física; ao destruir um ser humano ela elimina um ser social. O mundo a que pertence este indivíduo é automaticamente atingido, e deve então ser regenerado. Por isso os rituais funerários se assemelham aos rituais de criação. (...) a morte é uma criação invertida.

Renato Ortiz
\end{abstract}

O Brasil, pela junção de uma raça de sonhadores como os portugueses com a fantasia dos negros e o pavor indiano do invisível, está fatalmente à beira dos abismos de onde se entrevê o além. João do Rio

Mas que não se lamentem os mortos: eles sabem o que fazem.

Clarice Lispector

No conto "Eguns", do livro Abraçado ao meu rancor (publicado em 1986), o escritor paulistano João Antônio (1937-1996) traz um narradorpersonagem que, cansado de "malbaratar nos cafofos" e de "mariolar no guti-guti do brega", decide ir à Bahia, para a praia de Ponta de Areia, na Ilha de Itaparica, a fim de temporariamente se livrar do ambiente urbano onde vive, um cenário desencantado e tomado pela "poluição petroquímica". Sabedor de quanto e como a modernização e o capital se alastram e transformam o que deveria permanecer intocado, ele alerta, sobre a localidade baiana: "É de se ver, antes que acabe espetada de espigões" (p. 148).

O deslocamento espacial ("eu tenho chão pela frente, muito", p. 156) ganha foros de viagem iniciática, já que, por "sorte", por estar "recomendado por quatro obás" e graças ao empenho de um casal - a filha-de-santo Dety e seu marido Flávio, donos de um restaurante caseiro na praia de Ponta de Areia -, ele terá a chance de lá conhecer um terreiro de candomblé e de participar, pela primeira vez, de um ritual fechado e pouco comum: "uma festa de eguns. Rara" (p. 148). Tudo se dá, significativamente,

\footnotetext{
${ }^{1}$ Doutor em literatura brasileira e professor de teoria da literatura na Universidade Estadual Paulista (UNESP), Assis, São Paulo, Brasil. E-mail: bettomartins@uol.com.br.

2 No candomblé, os ministros do orixá Xangô.

3 Em outro trecho do conto, o narrador amplia a informação, ratificando o próprio privilégio, que os leitores passarão a partilhar. Afinal, é de prestígio, tradição e permanência que se trata: “Não sem
} 


\section{Gilberto Figueiredo Martins}

em um feriado de Páscoa, não apenas a indiciar o hibridismo que marca as relações das religiosidades afro-brasileiras com o catolicismo ${ }^{4}$, mas também a antecipar, com potência simbólica, que ali se renovará, em diferentes níveis, uma experiência outra de renascimento e continuidade: "No sábado de Aleluia, enquanto no resto da boa terra os candomblés estarão batendo e o Judas sendo malhado" (p. 148).

Sim, porque, para o pensamento religioso africano, os eguns ${ }^{5}$ são entidades ancestrais que regressam ${ }^{6}$, espíritos de mortos (geralmente de personalidades destacadas enquanto vivas, por terem exercido alta função social e/ou religiosa), almas de remotos antepassados masculinos que conservam sua individualidade no além, no mundo sobrenatural (òrun), e retornam à terra, ao mundo dos vivos (àiyêe ${ }^{7}$, quando invocados, por exemplo, em cerimônias de culto e homenagem como a que o narrador presenciará ${ }^{8}$. Nestas, os ancestrais

são preparados para proporcionar ajuda a quem a eles recorre, e o objetivo primordial de seu culto é o de orientá-los para que se tornem visíveis, para que o homem tenha uma melhor compreensão de um mundo que lhe é desconhecido! É através da preservação deste

motivo os nigerianos atravessam o oceano para ouvir e ver a festa fechada dos eguns, última restante ao Brasil, ao mundo. E que se abre, mesmo muito fechada, quatro vezes por ano. E só. Alguns raros, sapecados da sorte e escolhidos a vêem. O povo da nação ketu a preserva com firmeza. E desde o tempo em que a Bahia era a primeira capital” (p. 151). Nas notas e no corpo do texto, opto por acompanhar as citações de trechos do conto apenas de parênteses contendo o número da página da edição aqui utilizada (Antônio, 2001).

${ }^{4}$ Bastide (2001, p. 136) informa que o 2 de novembro, tido pelos católicos como o dia dos mortos, era outra data na qual se realizava, na Bahia, uma grande festa de eguns. Braga também confirma que, em Ponta de Areia, "muitos dos atos litúrgicos da Igreja Católica terminam por se integrar num mesmo continuum dos rituais afro-brasileiros” (1995, p. 51).

${ }^{5}$ Ver Santos (2008, p. 102-129) e D’ogun (2004, p. 27-31).

6 “Todo renascimento está relacionado com os ancestrais. A restituição de matéria simbólica e o renascimento (...) é que mantêm a relação e a harmonia entre os dois planos da existência. Os ancestrais são a garantia da continuidade, da evolução, da prosperidade” (Santos, 2008, p. 108).

7 “O egum se perpetua através das múltiplas reencarnações. Quando se trata de morto ilustre, os vivos podem cultuar sua memória, seu egum, que é assentado e recebe culto, como os orixás. Esse egum assentado não precisa mais renascer, sua memória foi eternizada. Sacrifícios votivos são oferecidos aos eguns que integram a linhagem dos ancestrais da família ou da comunidade mais ampla. Representam as raízes daquele grupo e são a base da identidade coletiva” (Prandi, 2005, p. 56-57).

${ }^{8}$ Mary Del Priore, com base na etnotanatologia de Louis Vincent Thomas, detém-se no estudo das práticas fúnebres do africano, o qual "minimiza a existência da morte: faz dela um imaginário que interrompe provisoriamente a existência da singularidade do ser; ele a transforma em acidente que só atinge provisoriamente a existência individual, poupando a espécie social. Daí a crença na onipresença dos ancestrais, na manutenção do ‘phylum’ clânico graças à reencarnação etc.. O procedimento lhe permite não apenas aceitar e assumir a morte, mas também a ordená-la melhor, integrando-a no seu sistema cultural. (...) Não ignoram a morte; ao contrário, afirmam-na desmesuradamente” (2006, p. 34-35).

44 estudos de literatura brasileira contemporânea, n.40, jul./dez. 2012, p. 43-61 
segmento da religião que conseguimos entender a continuidade da vida. (...) São eles que impõem ensinamentos morais, regras de convivência, de comportamento e de hierarquização, na religião ou no dia-a-dia do ser humano (Kileuy e Oxaguiã, 2009, p. 348-349).

A menção a Itaparica como cenário do conto não é mera marca de referencialidade, mas confere à narrativa considerável dimensão documental, pois foi nessa ilha baiana (e, sobretudo, na região da praia de Ponta de Areia) que mais fortemente se preservou a cerimônia afro-brasileira de culto aos ancestrais ${ }^{9}$, ao menos desde as primeiras décadas do século $\mathrm{XX}^{10}$ :

Ponta de Areia é uma comunidade de pescadores, localizada em Itaparica. Esta grande ilha que mede $46 \mathrm{~km}$ de extensão e $13 \mathrm{~km}$ de largura, situa-se na Baía de Todos os Santos. Apesar da pequena distância que a separa de Salvador, capital do Estado da Bahia, a comunidade de Ponta de Areia apresenta certas peculiaridades que lhe conferem específica identidade, especialmente por servir como estrutura de apoio a determinado grupo religioso. Instituída através de normas e valores que imprimem substrato de religiosidade em quase todos os setores de sua vida cotidiana, Ponta de Areia está sendo atualmente submetida a intenso processo de mudanças sociais, que tem provocado modificações no modus vivendi de sua população permanente. Aliás, tais mudanças vêm sendo observadas em todo o recôncavo baiano, sobretudo na Ilha de Itaparica (Braga, 1995, p. 23). ${ }^{11}$ Guiado pela curiosidade e por uma perspectiva que

\footnotetext{
9 Júlio Braga publicou os resultados de sua importante pesquisa acerca da organização sociocultural desse pequeno povoado - "onde o culto aos ancestrais é a experiência mais sagrada e vivida por sua população” -, buscando resgatar os traços essenciais de crenças e cultos a fim de configurar uma espécie de "fenomenologia da morte, tal como é vista e vivida pela população de Ponta de Areia, que a redefiniu a partir da experiência nagô-iorubá, mas que incorporou outras expressões de ancestralidade. Ali se cultuam ancestrais africanos e brasileiros e a morte, antes nagô, é hoje, indubitavelmente, uma morte afro-brasileira, cultuada nos padrões remanescentes dos cultos ancestrais da Nigéria e do Benim” (1995, p. 21).

10 Na seção iconográfica do livro de Juana Elbein dos Santos (2008, p. 250 e ss.), encontram-se duas raras fotografias (em preto e branco) de eguns, feitas durante uma cerimônia em terreiro da Ilha de Itaparica; e outra imagem, semelhante (mas ao ar livre), do mesmo rito em Abomey-Calavi, no Daomé. Ver, ainda, as fotos publicadas no estudo de Braga (1995, p. 83-93), onde aparece retratado - por Pierre Verger, em 1942 - o alabá babá mariô Antônio Daniel de Paula, "chefe” mencionado nominalmente no conto: “Antônio Daniel de Paula se levanta, eu me chego, na humildade. E ele, alto, tem de se curvar para o abraço” (p. 152). Por fim, no livro de Santos, aparece a informação de que "há evidências da origem de vários 'terreiros’ Égún, fundados pelos africanos, no decorrer do primeiro terço do século XIX” (2008, p. 119): na Ilha de Itaparica, o Terreiro de Vera Cruz, fundado em torno de 1820; o de Mocambo, em 1830; o de Tuntun, de 1850.

${ }^{11}$ Em outro capítulo do mesmo livro, o autor detém-se na análise dos aspectos econômicos do grupo que realiza os cultos de eguns na Ilha. Se, antes, era possível reaproximar "a comunidade do modelo típico de muitas sociedades africanas pré-coloniais”, agora isso “tende a desfazer-se na medida em
} 
se pode nomear (não sem excesso) de etnológica, o narrador acumula em seu relato expressões associadas ao campo semântico da visibilidade, indiciando que sua experiência na ilha será fundamentalmente dirigida por certa pulsão escópica ou, melhor dizendo, por um marcado desejo de ver. Assim, de início, seu olhar passeia respeitosamente pelo corpo de Dety ("A pele azeitonada, quase de índia", p. 148), mulher que lhe facilitará o acesso ao rito secreto. Além disso, no caminho para o local de culto, embora seja noite, é marcante a presença da lua, a qual, na praia "toda branca", "alumia feito dia": "o luar me deixa ver" (p. 149) e "Vista daqui, a lua cheia passeia" (p. 151) ${ }^{12}$. Ainda assim, ele e seus guias carregam "farolete", a abrir o caminho difícil, do qual são etapas "uma picada de piçarra" e uma "subida longa" pelo morro. A travessia vale a pena: "meus olhos viajam". Porém, quem tudo olha também é olhado e, mesmo "recomendado", o visitante do Sul desperta desconfiança: "o ojeje ${ }^{13}$ me examina sem pressa, indireto, meio distante, olhando as roupas com uma calma desconhecida" (p. 149); “Ignoram a minha presença e, depois, me olham” (p. 149); " (o chefe do terreiro) Vai de olhos no visitante, demorado, quieto" (p. 152).

Aceito, o homem já passa a gozar de algum reconhecimento no grupo, recebendo o epíteto comum, destinado aos que adquirem o novo vínculo relacional de parentesco religioso: "compadre"14. Estranha, mas gosta:

que avança e se plasma, definitivamente, uma mentalidade capitalista nas relações de produção, com reflexos imediatos nas relações sociais, em uma comunidade onde, até há pouco tempo, imperavam o espírito associativo e o coletivismo na obtenção dos bens essenciais à subsistência. Essas mudanças se devem, em grande parte, à consolidação da Ilha de Itaparica como um dos mais importantes sítios de recreação e lazer para a classe média da região metropolitana de Salvador” (Santos, p. 49-50). Tais informações, infelizmente, reforçam o acerto e a pertinência da ideia exposta no início do conto, quando o narrador alerta para o risco de a localidade acabar “espetada por espigões” (Antônio, 2001, p. 148).

12 O satélite também se faz presente no relato do mesmo culto em Varanda: “A lua cheia já está bem alta quando do asfalto se ouve a voz aguda das mulheres nos seus cantos e o tom grave dos atabaques, dando seus primeiros toques de reverência aos Eguns” (1985, p. 62).

13 O sacerdote: “Os Ojé são, pois, os intermediários entre os vivos e os mortos. Têm a responsabilidade de tornar os espíritos ancestrais visíveis e fazê-los aparecer em público” (Santos, 2008, p. 127). ${ }^{14}$ Mais adiante, será chamado de "mano" (p. 150). É reincidente, nos estudos sobre as religiosidades afro-brasileiras, a referência a tal vinculação simbólica de fundo parental estabelecida entre seus praticantes. Em ensaio anterior, no qual analisei a peça teatral Balbina de Iansã, de Plínio Marcos - uma adaptação de Romeu e Julieta, só que ambientada em terreiros de candomblé paulistas -, chamei atenção, respaldado em Prandi (2005, p. 232), para o fato de que "termos como mãe, filho, casa, correntes nesse ambiente sociocultural dos terreiros, indiciam a dimensão relacional dos vínculos entre os membros do grupo, como simulacro da configuração familiar, pautado em 'relações protocolares de parentesco iniciático’” (Martins, 2010, p. 65, nota 8). Referindo-se especificamente aos habitantes de Ponta de Areia, Braga (1995, p. 44) confirma: "Na verdade, a comunidade transcende os limites de parentesco por consanguinidade e envolve a todos, conjuntamente, num parentesco religioso mais amplo - mágico e simbólico - que os leva a participar de uma experiência comum no que se refere às relações de ancestralidade”.

46 estudos de literatura brasileira contemporânea, n.40, jul./dez. 2012, p. 43-61 
"De onde tirou o compadre não sei. Mas já me alegra. Regulou" (p. 149). Junto com a deferência do título, um tratamento gradativamente mais personalizado: "Querem saber, meigos mas firmes" (id.); "a partir daí, sou tratado sem distância" (p. 150); "Só não me revistarão porque vim pela mão de um ojé" (p. 151). No entanto, o privilégio gera necessária contrapartida, a fim de se garantir a definitiva identificação: "- De que nação é o rapaz?". A pergunta deixa o visitante em estado de derrelição e fragilidade, constrangido e confuso, já que desconhecedor de suas próprias raízes de ancestralidade, por outro lado tão caras àqueles que passa a conhecer: "E eu sei de que nação sou? Eta! Estou espetado, feito menino. Como saberei?" (p. 150) ${ }^{15}$. Mas logo será auxiliado pelo outro ojé, que o conduz ("parece me topar"), e que trata de, generosa e marotamente, filiá-lo de imediato a alguma tradição e região geográfica - a "do povo da umbanda $^{16}$, lá no Sul" (p. 150).

Antes mesmo de chegar ao local onde se dará a festa, começa a presenciar mais indícios ritualísticos: o ojé que lhe serve de guia traz na mão "uma vara branca e comprida, de pau acabado de descascar, com certeza" e veste "um barrete magnífico. Todo vermelho, brilhante, com desenhos brancos e verdes" (p. 149). Inicia-se a preparação para o ingresso no sagrado, um tempo-espaço novo, com um ritmo outro... Logo encontram pelo caminho mais dois "homens enormes", que passam a integrar a comitiva, também eles portando "varas brancas, altas como eles", levadas como cajados". O narrador logo saberá o porquê de tal insígnia comum ao grupo:

\footnotetext{
${ }^{15}$ Significativamente, a partir daí, fica mais comum para o narrador referir-se aos celebrantes utilizando o viés identitário, como “os da nação ketu” (p. 150).

${ }^{16}$ Na umbanda, religião mais marcadamente brasileira e que agrega, entre outros, valores e preceitos do espiritismo kardecista, há diferenças nas relações com os eguns, descritas com mais pormenores no livro de José Ribeiro: “A Linha das Almas, ou Linha dos Eguns, como é conhecida, tem grande força espiritual, pois nela baixam todos os Eguns, de todo o ritual, trabalhando também em legião de espíritos da Natureza, que são Orixás, mas, quando baixados, na mesa das Almas, são de muita utilidade, sendo que esses espíritos só baixam depois das vinte e três horas, havendo, entretanto, exceção, quando baixam a qualquer hora para 'sacaãnga'/desenterrar (malefícios)” (s/d, p. 39). Apontando para o fenômeno brasileiro de umbandização do candomblé, Prandi afirma que, graças a esse processo, "os eguns, que são na concepção iorubá ancestrais particulares de uma específica comunidade, vão perdendo suas características africanas para se transformar em entidades genéricas não ligadas a nenhuma comunidade de culto em particular, que 'baixam' nos terreiros para 'trabalhar' e assumem a justificativa da caridade, ideal e prática cristã-kardecistas. Aos poucos, tais ideias vão suplantando os modelos africanos de ancestralidade com seus ideais de culto à origem e valorização das linhagens” (2005, p. 65).

${ }^{17}$ Chegando ao barracão onde se dará a festa, o narrador encontra outros três ojés, "gente de aí, alta, uns dois metros”, fazendo com que ele próprio se sinta conduzido como “uma criança”. Curiosamente, Braga refere-se à história de "certo senhor conhecido pela alcunha de João-Dois-Metros, numa clara alusão ao tamanho deste prestigioso líder religioso do terreiro da Encarnação, localizado no povoado de igual nome, na Ilha de Itaparica” (1995, p. 27).
} 
O ojé marcha e me diz por que a vara branca - icham - na mão. Hoje é noite de eguns; estão soltos e vão dançar. Ficam pelas matas aporrinhando e pegando o pé dos filhos de fé que ainda estão vivos. Mas egun respeita uma vara branca. Frente a ela, não avança. (p. 150).

\section{(...)}

Ninguém nem chegue perto de um egun. Nem um ojé. Eles matam com suas armas afiadas, adagas, punhais, punhaletes, espadas que brilham ${ }^{18}$. Dos vivos, não gostam. Vai daí, os ojés os dominam usando as varas brancas. Não os dominam, redigo, os amenizam só, assustando. Que um egun ninguém domina (p. 153).

Na tradição do culto, os ixãs são bastões sagrados usados para controlar os eguns, evitando que os ancestrais se aproximem dos vivos, já que tal contato físico ofereceria um risco mortal ${ }^{19}$. No conto, os espíritos ancestrais são personificados, recebendo características humanas, que reforçam o vínculo entre os dois mundos - ou dois níveis de existência - paralelos: São misteriosos, cheios de caprichos, teimosia e raiva contra os vivos. Exigem muita atenção, cantoria, candongas. Gostam, então. Mas só dos mimos, não de quem os dá. Eles são os espíritos dos mortos. E, para os do candomblé, mortos não cruzam bem com vivos. Ainda que os agradem com cerimônias candongadas, homenagens, abalés ${ }^{20}$ (sic) e muitos cantos bonitos (p. 150).

Mesmo do lado de fora do barracão onde se dá a cerimônia invocatória, "um grupo maior de ojés circula (...), encarregado do trabalho de proteção da comunidade religiosa contra a presença indesejada de eguns ainda não socializados pelos rituais de consagração ('tomar roupa') que circulam livremente durante a noite, provocando pânico em toda a comunidade

\footnotetext{
18 Ao tratar do assunto, Ziegler é categórico: “Quem quer que tenha sido tocado pelas franjas, os babados, ou as luvas dos Egun é fulminado. A evidência traduzida pelo mito repousa na observação empírica. De fato, as pessoas que por descuido se deixam tocar pela roupa de um Egun sofrem graves problemas psiconervosos e psicossomáticos” (1977, p. 69).

19 "Com efeito, os Baba (eguns) trazem para seus descendentes e fiéis o benefício de sua benção e de seus conselhos, mas eles não podem ser tocados e ficam sempre isolados dos vivos. Sua presença é rigorosamente controlada pelos Òjè e ninguém pode aproximar-se dos Egúngún" (Santos, 2008, p. 120). D’ogun completa: "Há o perigo do contato pessoal do assistente com o Egun. Segundo falares das comunidades, o contactante poderá tornar-se um 'assombrado', vítima de perigo permanente. Caso isso aconteça, períodos de purificação deverão ser ministrados com a finalidade de afastar os aparecimentos de doença, ou até da morte. Sendo o Egun a própria materialização da morte sob as tiras de pano, o mais simples contato ou esbarrão é altamente prejudicial. Até mesmo os Ojé-Atokun, qualificados sacerdotes, guias, invocadores e zeladores de Eguns, desempenham todas essas missões sem substituírem as mãos pelo ixã (sic)” (2004, p. 30).

${ }^{20}$ Provavelmente alabês, em referência aos toques de atabaque.
} 
religiosa" (Braga, 1995, p. 46) ${ }^{21}$. São os membros desse exército que o personagem-narrador encontra pelas curvas da "estradinha". E sobre seus costumes a atenção descritiva ainda se detém, seja sobre o modo como se cumprimentam ("é um abraço em que as cabeças se cruzam e os ombros também. Há um toque de leve na altura das clavículas", p. 149) ou reparando na língua estrangeira com que se comunicam ("Os ojés falam em ioruba", p. 149).

Os sentidos são despertados ao se aproximarem do "arraial", uma "roça grande, toda cercada", "quilombo vasto": o "barracão ou galpão caiado de branco", local de culto, de onde vem "a batida desenfreada, rítmica" dos atabaques, "chamando, prendendo, alegrando" (p. 151). Era de "tremer o mato". Junto aos sons ritmados dos instrumentos, o "canto de muitas vozes de mulheres" (p. 150). Daí para diante, o entusiasmo do narrador é crescente e o estilo do relato timbra-se de hipérboles: "Era preciso que se criassem vinte missas lubas ${ }^{22}$ para chegarem a esta beleza de canto" (p. 151). No espaço ritualístico, há a necessidade de obedecer às normas de conduta, às regras de organização e funcionamento do terreiro, pois "os eguns têm fundamento" (id.). Já na entrada, a reverência gestual frente a uma vela acesa ${ }^{23}$. E então, portas cerradas. Agora, só será permitido sair "ao raiar do dia, de festa acabada", avisam-no, e ele nos diz: "Entrei".

\section{Uma senzala festando}

O livro de Juana Elbein dos Santos, centrado na "descrição e interpretação dos elementos e dos ritos associados à morte" (2008, p. 15), é um dos mais reconhecidos dentre os estudos sobre o tema, principalmente por adotar rigorosamente uma perspectiva "desde dentro, isto é, a partir da realidade cultural do grupo" (p. 20) ${ }^{24}$. Nele, se reafirma um dado oferecido pelo

\footnotetext{
${ }^{21}$ No conto, referindo-se aos eguns, relata o narrador: “Além de baixarem no terreiro, rondam a roça, fantasmando, tencionando atacar os vivos com suas armas pelas janelas do barracão. Perturbam, azoam. Os ojés não têm sossego, correm a afastá-los, distanciá-los. As varas batem o chão, que estalam” (p. 154).

${ }^{22}$ Referência a regiões do sul do Congo, onde há aldeias nas quais mulheres praticam a agricultura.

${ }^{23}$ Provavelmente se trata de algo equivalente ao "Ossum - um monte de terra onde estão fincadas algumas velas e uma quartinha d’água” e onde ficam depositados todos os pertences do egun. Ver Varanda (1985, p. 65).

24 "Devido a que a religião Nagô constitui uma experiência iniciática, no decorrer da qual os conhecimentos são apreendidos por meio de uma experiência vivida no nível bipessoal e grupal, mediante um desenvolvimento paulatino pela transmissão e absorção de uma força e um conhecimento simbólico e complexo a todos os níveis da pessoa, e que representa a incorporação vivida de todos os elementos coletivos e individuais do sistema, parece que a perspectiva que convencionamos chamar desde dentro
} 
conto, o de ser um verdadeiro privilégio o acesso de um sujeito não iniciado ao culto dos eguns. A autora chega a destacar a dificuldade enfrentada até mesmo pelos acadêmicos que pretendem se dedicar à compreensão das práticas litúrgicas da comunidade:

É verdade que, insistindo, os pesquisadores, às vezes, conseguem assistir à cerimônia, transgredindo um dos princípios fundamentais do sistema. (...) Há uma proibição para certa categoria de indivíduos. De fato, pouquíssimas pessoas têm acesso a essas cerimônias. (...) $\mathrm{O}$ acesso a determinados ritos está em relação direta com o grau de iniciação e, conseqüentemente, com a capacidade física e espiritual do indivíduo de assistir e de participar de uma experiência durante a qual são liberados e estão presentes forças e poderes dificilmente manejáveis (Santos, 2008, p. 20-21). ${ }^{25}$

O narrador de João Antônio participa de outro grupo singular - também composto de poucos iniciados -, que reafirma a centralidade da dimensão da experiência (em sentido forte) para a configuração da narrativa, nisto se aproximando, inclusive, ainda que pela via do registro escrito, do universo de concepções e valores do próprio segmento sociocultural retratado no conto.

No célebre ensaio "O narrador", Walter Benjamin (1994, p. 200) tece conscienciosas e polêmicas considerações acerca do risco de extinção que estaria correndo, na era da informação, a "arte de narrar". Segundo o pensador alemão, isso se verificaria com a "evolução secular das forças produtivas", devido à gradativa privação da nossa "faculdade de intercambiar experiências", as quais seriam cada vez "mais pobres" e "mais radicalmente desmoralizadas". Assim, os antigos narradores anônimos tivessem sido eles marinheiros comerciantes ou camponeses sedentários e viajantes - ainda teriam tido a chance de vivenciar a autêntica "experiência que passa de pessoa a pessoa", fonte significativa de suas histórias

se impõe quase inevitavelmente. É certo que a absorção de uma série de valores coletivos e individuais e o fato de os viver numa inter-relação de grupo não é suficiente aos fins de uma análise e de uma interpretação desses valores. É preciso, pois, colocá-los em perspectiva e reestruturar conscientemente os elementos, suas relações particulares, revelando assim seu simbolismo” (Santos, 2008, p. 17). E a autora completa: "É neste nível que se elabora a perspectiva desde dentro para fora; isto é, a análise da natureza e do significado do material fatual, recolocando os elementos num contexto dinâmico, descobrindo a simbologia subjacente, reconstituindo a trama dos signos em função de suas inter-relações internas e de suas relações com o mundo exterior" (p. 23).

${ }^{25}$ Também o livro de Ziegler destaca a recusa dos dirigentes do candomblé de Itaparica "em abrir-se a pessoas que não pertençam ao clã, aos aliados, agregados, ou estranhos em pequeno número e cuidadosamente selecionados", fiéis ao princípio: "nada de sincretismo e sim uma extrema resistência à aculturação” (1977, p. 61). Ver, finalmente, Varanda (1985, p. 64-65). 
orais. O "senso prático" encontrava-se na natureza destas que constituíam, para ele, o espírito da "verdadeira narrativa", anterior ao surgimento do gênero romance e ao predomínio da imprensa, que vive de produzir informação somente sobre o que é próximo e imediato. E o ensaísta conclui, sem disfarçar certo tom nostálgico em seu melancólico diagnóstico sobre os novos tempos que então se anunciavam:

"Quem viaja tem muito que contar", diz o povo, e com isso imagina o narrador como alguém que vem de longe (Benjamin, 1994, p. 198).

O saber que vem de longe encontra hoje menos ouvintes que a informação sobre acontecimentos próximos. O saber, que vinha de longe - do longe espacial das terras estranhas, ou do longe temporal contido na tradição -, dispunha de uma autoridade que era válida mesmo que não fosse controlável pela experiência (Benjamin, 1994, p. 202-203).

Parece advir daí também a espécie de introito na abertura do conto até mesmo graficamente isolado do conjunto -, que reclama a perda do reconhecimento da condição de excepcionalidade da localidade afastada, ainda marcada por costumes e práticas tradicionais, mudança esta ocasionada pelo avanço da força homogeneizadora do capital e do progresso, que tende a tudo igualar, metamorfoseado em mercadoria. Lugar singularizado pelo rito e ofício auratizado da escrita se equivalem, portanto, como ameaçados espaços de resistência ${ }^{26}$. Transmitindo o que viu - e respeitando os limites do que pode ser conhecido e relatado por um leigo ${ }^{27}-$, inclusive utilizando muitas vezes os verbos no presente, o narrador reatualiza o rito a cada novo leitor, revitaliza o visto a cada leitura, perpetuando o

\footnotetext{
${ }^{26}$ Eis outro importante trecho do conto, que deixa claro o lugar de fala do narrador e sua respeitosa admiração pelo que enuncia: "Estes atravessaram quatrocentos anos de resistência e guardaram os seus trazidos da África. Tiveram de manter os seus cantos e danças, dissimulada, sorrateiramente, escondidos nos morros, encafuados nos matos, nas senzalas. Quilombados. Resistiram ao chicote, aos grilhões, ao pelourinho, à estupidez da escravidão. E estão aí, vivos. Vou lá eu, mestiço ou mulato claro e nascido livre, filho deste com aquela, me meter na investigação da profundidade dos eguns? Quatrocentos anos. E até posso espiá-los, dentro do meu desconhecimento da seita, e fui recebido com reverência” (p. 154).

27 "É verdade que o único candomblé de Egun existente na diáspora nagô do Brasil, o terreiro de Amoreira (nas colinas de Itaparica), é protegido por redes superpostas de saber hermético. Esses conhecimentos são estratificados. Cada saber particular de uma classe é protegido por uma linguagem secreta que lhe é específica. Permanece impenetrável a quem não pertença ao estrato detentor do saber que lhe é próprio (aliado, agregado, ou estranho). (...) Todo o saber social nagô é assim hierarquizado, protegido, 'secretizado'” (Ziegler, 1977, p. 59).
} 
culto que teimam em fazer desaparecer ${ }^{28}$ e participando - ainda que de forma mediada - da vivência cultural alteritária:

Neste ponto, o homem nagô afirma a sua brilhante superioridade. Graças ao Egun sabe aquilo que antes dele foi vivido, sofrido, sonhado; conhece, no sentido mais marcante do termo, a vida vivida, as experiências sofridas, os amores sonhados pelos seus predecessores. Desta montanha vital retira ensinamentos insubstituíveis. Mesmo em sua vida precária de subproletário negro, o homem nagô se encontra apoiado por uma perspectiva ontológica, que esvazia em grande parte a sua angústia da morte e lhe restitui, em sólidas estruturas, numa límpida linguagem ritual, a certeza de sua própria imortalidade (Ziegler, 1977, p. 70). ${ }^{29}$

Na segunda metade da narrativa, ingressamos, definitivamente, na descrição dinâmica da cerimônia, ocorrida no espaço ritualístico, a saber, a casa de culto dos Baba-égún em Itaparica, o Ilé-igbàlè. Aí os espíritos ancestrais masculinos são invocados e podem assumir sua forma corporal, com nome próprio, e "vestidos de maneira que os singulariza" (Santos, 2008, p. 105-106):

Os Egúngún, Baba Égún, ou simplesmente Baba, espíritos daqueles mortos do sexo masculino especialmente preparados para ser invocados, aparecem de maneira característica, inteiramente recobertos de panos coloridos, que permitem aos espectadores perceber vagamente formas humanas de diferentes alturas e corpo. Acreditase que sob as tiras de pano que cobrem essas formas encontra-se o Égun de um morto, um ancestre conhecido ou, se a forma não é reconhecível, qualquer aspecto associado à morte. Nesse último caso, o Egúngún representa ancestres coletivos que simbolizam con-

\footnotetext{
${ }^{28}$ Como exemplo dos percalços por que passa uma religião tida por subalterna para ter legitimado seu espaço social no conjunto de crenças de um povo, o livro de Braga (1995, p. 31-32) traz a íntegra de uma reportagem publicada no jornal A Tarde, do dia 21 de junho de 1940, com o título "Varejada a igreja negra e presos os bárbaros sacerdotes", e o subtítulo "Amoreiras, em Itaparica, era um reduto do fetichismo". No texto jornalístico, há referência à apreensão de "copioso material da liturgia fetichista" e de um "casal de pais-de-santo", parentes de Antônio Daniel de Paula, mencionado nominalmente no conto de João Antônio. Segundo a reportagem, de teor eminentemente sensacionalista, esse religioso teria fugido durante a invasão ao terreiro e estaria, então, "sofrendo severa perseguição por parte de investigadores, que se acham no seu encalço”.

${ }_{29}$ E, ainda, em outro momento do mesmo livro: "A função primordial do terreiro de Egun consiste, portanto, em reencarnar os mortos, colocar os vivos sob os benefícios regulares da experiência acumulada pelos antepassados e estabelecer uma comunicação socializada, controlada e ordenada entre os que se encontram no momento entregues a sua aventura humana e os outros que já percorreram essa existência” (Ziegler, 1977, p. 66).
} 
ceitos morais e são os guardiães de herdados costumes e tradições (Santos, 2008, p. 120).

No conto, o narrador descreverá mais detalhadamente a aparição de dois desses espíritos, mas afirmará depois, de forma sumária: "Há três ou quatro eguns de uma só vez, lá na frente. E, assim, noite toda" (p. 154).

No entanto, antes de admirar os donos da festa, volta a deter sua atenção nas mulheres presentes dentro da "senzala" ${ }^{30}$, agrupadas de modo a permanecerem separadas dos homens: estes à direita, elas à esquerda ${ }^{31}$ - "e que gente bonita! Meus olhos viajam primeiro para o lado das mulheres, onde os tipos de beleza se multiplicam em algumas idades. Sentadas no chão ${ }^{32}$, meigas, madonas, donas, meninas, sensuais e cantando" (p. 151). Ainda mais uma vez, profere - reiterando-a como que ritualisticamente, feito uma rítmica fórmula mágica que condensa a sabedoria recentemente apreendida -, a frase que justifica a função dos ojés, que "protegem o povo, fazendo uma barreira com as varas brancas": afinal, "Eguns não gostam de gente viva" (p. 152). No culto de Itaparica, as mulheres não podem ser imortalizadas sob a forma de egun, nem participam dos segredos e mistérios das atividades secretas da seita. Contudo, "participam ativamente das cerimônias do culto, oferecem sacrifícios, e lhes é permitido principalmente entoar cânticos característicos dos Egúngún por ocasião dos festivais anuais" (Santos, 2008, p. 123) ${ }^{33}$. E assim, como se viu, elas aparecem no conto: "Os cantos vindos das mulheres são lindos"; "o mulherio comovente, os cantos são selvagens, doloridos ou efusivos como o quê, arrebentando de alegria. Muitas palmas são puxadas pelas mulheres e seguidas pelos homens no acompanhamento dos cantares" (p. 152). Ao final da narrativa e da festa, quando ainda "as duas primeiras fileiras de mulheres não esfriaram entusiasmo" (p. 155) e algumas outras "vão servir a comida, com as primeiras luzes do sol", restam tempo e disposição ao

\footnotetext{
${ }^{30} \mathrm{O}$ narrador insiste em destacar a negritude da pele que marca, como traço identitário, o povo que frequenta o culto, utilizando termos como "quilombo", "senzala”, sendo ele próprio - "mestiço, mulato claro" - apenas uma "exceção".

31 "Esta parte de uso público é que estabelece a separação por sexo - homens do lado direito de quem entra e mulheres do lado esquerdo -, tal como em qualquer terreiro de candomblé jêje-nagô” (Braga, 1995, p. 37).

32 “Todos cantam para Egun, mas são as mulheres que dão toda a vida desde o primeiro canto de reverência aos Eguns. Elas são as mais vigiadas durante todo o ritual. O culto de Egun é uma seita privativa dos homens: às mulheres é apenas permitido que assistam no barracão, assim mesmo sentadas sobre o ikunlê (esteira), enquanto os homens - em outra ala - acham sempre um lugar nos bancos. Apesar disso, são as mulheres que também vão cantar no centro do barracão. Fazem uma fila, vestidas de baianas, e batendo palmas rondam os presentes que vão oferecer aos eguns” (Varanda, 1985, p. 63-64).

${ }^{33}$ Ver também Ziegler (1977, p. 46-47).
} 
narrador para reparar na "cadência do andar" das moças (e, por tabela, no passo inevitavelmente sestroso dos rapazes) e para desejar, concupiscente e já reinstalado no tempo-espaço profano da normalidade: "Crescidinhos, de mulher. Lá no quilombo, já me lembro. O peito da menina dentro da blusa branca balangava dois seios soltos" (p. 156).

Mas, deixemos, por ora, os corpos e voltemos aos espíritos. Tal como confirmam os depoimentos de pesquisadores especializados nessa festa - a qual "nada tem a ver com orixás ou com o comum do candomblé. É única" (p. 152) -, o espaço "apinhado, atopetado" no qual se encontra o personagem-narrador é a porção pública do terreiro, ocupada por iniciados e fiéis, onde são realizados os rituais coletivos; em seguida, outra parte do grande salão também é retratada, um "espaço semiprivado transitado unicamente pelos iniciados de todas as categorias sem distinção e onde às vezes um não iniciado pode ter acesso se está acompanhado de um sacerdote do culto" (Santos, 2008, p. 124); nele ficam o trono e as cadeiras destinados aos eguns mais elevados hierarquicamente e onde estes aparecem para "receber as oferendas, dançar, cantar, benzer, dar mensagens, enfim 'visitar' e festejar ao lado de seus descendentes" (Santos, 2008, p. 124). Tendo sido presenteado com um lugar privilegiado, "no banco lá da frente, perto dos atabaques e antes dos ojés", o visitante pode observar sem barreiras "a fileira de poltronas e tronos variados numa mistura desconcertante de tamanhos, enfeites, espelhos, cetins", já sabendo, inclusive, que "os eguns escolherão ou não. São caprichosos" (p. 152). Finalmente, o espaço estritamente privado, destinado apenas aos ojés, onde se encontram os assentamentos dos eguns, também é mencionado no texto ficcional:

Dizem que dentro de uma câmara, lá no escondido e pegado ao galpão, ficam, num quarto, as roupas dos eguns. Durante dias, antes da cerimônia, sacrifícios lhe são oferecidos, comidas e um carneiro. Chegada a noite de baixarem, os espíritos se materializam nas roupas (p. 153). ${ }^{34}$

O conto de João Antônio assemelha-se muito ao relato feito por Jean Ziegler, em seu livro, publicado na França em meados da década de 1970 e traduzido no Brasil em 1977. O caminho dificultoso até chegar ao terreiro, a desconfiança inquiridora dos ojés frente ao estranho visitante, o contato com importantes membros idosos de uma mesma família ou clã, o apoio dos guias, a segregação do espaço entre homens e mulheres, a

34 “Entre as construções, no limite do espaço ‘urbano’ e debruçados sobre o ‘mato', encontra-se o Ilê$I b o-A k u$, a casa onde são adorados os mortos e onde se encontram seus 'assentos' - lugares consagrados - local onde ninguém se pode aproximar, guardado por sacerdotes preparados para estes mistérios e separado do resto do ‘terreiro’ por uma cerca de arbustos rituais” (Santos, 2008, p. 34). 
presença e função dos "servos do bastão", o encantamento emocionado de quem participa pela primeira vez de uma festa dos eguns, tudo aparece em ambos, no ensaio acadêmico e na narrativa de ficção:

Entramos. Meus olhos, pouco habituados às luzes fugidias dos lampiões de petróleo, percebem um surpreendente espetáculo. A casa é dividida em dois espaços distintos, um reservado aos mortos, o outro aos vivos. $\mathrm{O}$ dos vivos é dividido ao meio por uma cerca de madeira. De um lado, à direita, os homens, velhos e meninos encontram-se sentados em bancos rústicos. À esquerda, deitadas em esteiras, as mulheres. Somente o rosto, os braços e as pernas emergem dos lençóis brancos recém-lavados (Ziegler, 1977, p. 50).

A semelhança é ainda maior no que diz respeito à descrição dos eguns que, de repente, irrompem no salão. No livro do então professor de sociologia em Genebra, lemos:

Súbito, bem distante, uma voz, uma espécie de prolongado grito gutural, corta a noite e se aproxima. É um som totalmente inumano. Estremeço. A memória fônica não encontra nenhum ponto de referência. Nenhum som tem parecença com aquele. Para os africanos presentes é a voz dos mortos. Ouço um ruído vindo da porta dos fundos (do lado sudeste). Um após outro surgem cinco Egun. Entram, silhuetas magnificamente vestidas e com passo deslizante, rodopiam várias vezes sobre si mesmos, esboçam uma breve ronda e deixam-se cair nos seus lugares, belas cadeiras de madeira que se encontram alinhadas ao longo da parede, nos fundos do terreiro, no espaço que lhes foi reservado.

$\mathrm{O}$ aparecimento dos Egun exerce indiscutível fascínio em toda a multidão, mesmo naqueles que não se sentem totalmente submissos ao seu poder. (...) A entrada dos Egun e sua sessão em companhia dos vivos é um espetáculo de qualidade, revestido de grande solenidade (Ziegler, 1977, p. 51-52)

O excerto é longo, mas nele a descrição permite entrever na perspectiva do observador a oscilação entre um ponto de vista pautado na avaliação rigorosa, de intencionalidade científica, e a entrega total ao que sabe a espetáculo e rito, numa participação quase fusional, que obnubila a razão e exige adesão e entrega absolutas. A experiência paroxística põe em xeque, inclusive, a própria capacidade da linguagem de definir e relatar o visto,

\footnotetext{
${ }^{35}$ Guilherme D’ogun (2004, p. 29) confirma: “o Egungum, ao surgir no recinto, procura, simplesmente, causar impacto visual, utilizando-se da surpresa como arma ritualística”.
} 
beirando, por vezes, o silêncio a que obriga a indizibilidade radical do que é intensamente vivido: "É impossível descrever a roupa com maiores detalhes", dirá o estupefato pesquisador em outro trecho.

Já no conto, acumulam-se expressões que denunciam o esforço de definição e de registro de um escritor mais afeito a transcrições do efêmero e do abstrato, como se sabe, um exímio perito em retratar aquilo que permanece à margem das representações dominantes ${ }^{36}$. Mesmo assim, avultam no texto o desconcerto e a falta de ancoragem asseguradora do que é (re)conhecido. Ultrapassado o primeiro impacto do contato presencial com a cerimônia e já distanciado em tempo e espaço outros, o narrador luta para resgatar, pela memória afetiva, a matéria da escrita, embora não possa impedir, várias vezes, que se rompa o limite do gênero conto-reportagem de viés etnográfico, sendo o depoimento turvado aqui e ali pela flagrante comoção:

Meu coração apertado entre a beleza das vozes e o medo do chefe me rejeitar.

(...) Coração louco, comovido, uns dez minutos sentado, sem saber onde prenda os olhos, onde vá a atenção. Os tronos são lindos, os atabaques mexem com os pêlos do braço (p. 152).

Dá-se o engraçado. Se me dá. Nenhuma necessidade de provar a veracidade dessas informações que cantam e dançam, como não chego a sentir medo do egum, nem o ambiente me é estranho. Aturdido e maravilhado, sim e bem. Uma enxurrada de beleza, pureza, de cores, sons, de crença. (...) E, nestas belezas, até homem de pouca fé se comove (p. 154).

O primeiro egun a aparecer na festa em Itaparica assemelha-se aos que são descritos em outros textos, mais efetivamente referenciáveis: recobertos por tecidos cortados em tiras e franjas coloridas (o abala), corpos habilmente camuflados, com pés e mãos ocultados, continuamente em movimento (Ziegler, 1977, p. 52):

Lindo de colorido. Surge o primeiro egum, estalando pela porta, avançando com uma espada e um punhal. Não se vêem as mãos. Mas há os braços, e ele tem forma humana, plenamente. (...) O egum se aquieta, toma o ritmo e começa a dançar. Canta também, em ioruba, sua voz empastada, rouquenta, como vinda de um fundo

\footnotetext{
${ }^{36}$ Ver Oliveira et al. (2008) e Boletim Proleitura (1997).

56 estudos de literatura brasileira contemporânea, n.40, jul./dez. 2012, p. 43-61
} 
misterioso qualquer. Mas que não viesse de dentro dele mesmo. Rouquenta, devagar, monocórdica. O povo conversa com ele em africano (p. 153) 37 .

Segundo Juana E. dos Santos, cada Égún-àgbà possui vestimentas e sons característicos que o distinguem, incluindo um awon, "peça de rede com a aparência de um rosto, inserido numa espécie de macacão que aparece vagamente sob o abala" (este, por sua vez, o "conjunto de tiras multicores, que caem como uma cortina, presas numa parte sólida, quadrada ou redonda, que forma o topo"). Todavia, comparecem ao culto, ainda, representantes do grupo dos Apáàràká, os eguns que "não têm abala, mas apenas um pano muito colorido de forma quadrada ou retangular; sem awon, são desprovidos de rosto e voz. São mudos e não identificados. (...) são espíritos novos que, por várias razões, não puderam chegar ao estado agbá e cujos ritos de formação não foram acabados" (Santos, 2008, p. 127). A considerar o que diz o narrador, um desses espíritos também acabou por comparecer à festa registrada no conto:

Estala outro egum, surge num tropel, com estrondo pela porta adentro. Este não tem forma humana, que nada. Nem é tão colorido, nem sua roupa é o artesanato fulgurante do primeiro egum, com espelhos, vidrilhos, palmeiras, bananas, sóis, ocres, carmins, luas alaranjadas, cores fortes e quentes, africanas. Ele é quadrado, enorme, se atiça amalucado, inquieto, como que revoltado ${ }^{38}$. Preto de um lado, vermelho de outro. Mas não tem frente nem costas. É um quadrado. Um espírito ainda sem luz, vagando no espaço, sofrendo depois da desencarnação (p. 153-154) $)^{39}$.

\footnotetext{
37 Jean Ziegler chega a se referir ao som emitido pelos ancestrais como "voz aterrorizante de ventríloquo embriagado". E completa: "O Egun responde, ordena, aconselha e, na maioria das vezes, admoesta. Sua voz provoca uma impressão aterrorizante, que não se dissipará por toda a noite. Incompreensível para o comum dos fiéis, a língua falada pelo Egun é hermética, constituída de palavras do ioruba arcaico" (Ziegler, 1977, p. 52). Juana E. dos Santos complementa: “Os Égun falam de uma maneira muito particular: alguns com uma voz rouca e cavernosa. Outros falam muito baixo, mas com uma voz muito aguda. (...) os Égun falam com uma voz que não é humana. (...) A maneira de Égun falar é chamada ségi, na Bahia, e sua palavra tem força de lei” (2008, p. 127-128).

${ }^{38}$ Segundo Varanda (1985, p. 61), a inquietude e o nervosismo desses espíritos dever-se-iam justamente ao fato de eles serem mudos.

39 “No candomblé de Babá Egum existe uma divisão hierárquica para o melhor entendimento das suas liturgias. Não são todos os Eguns que podem vir ao aiê trazer sua ajuda. Isso é prerrogativa somente dos Babá-agbás, aqueles mais antigos, mais velhos, que são preparados liturgicamente e doutrinados, recebendo o direito de poder falar (ké), se expressar verbalmente. Existem também os aparacás, Eguns que não falam e que, por não constituírem individualidade, não têm nomes ou simbologias que os identifiquem. Os aparacás são os ancestrais mais novos e que não alcançaram o estágio de Babá Egum. A eles cabe geralmente a função de fiscalizar e administrar as partes exteriores dos Ilês de Egungun. Se necessitarem transmitir alguma mensagem a alguém, utilizam-se do auxílio dos Babás” (Kileuy
} 
Tudo o visitante observa e depois descreve, sempre com a "humilda$\mathrm{de}^{\prime \prime}$ e a reverência de quem presencia a irrupção do sagrado no mundo e com a admiração espantada de quem reconhece a potência estética de um cerimonial religioso. E, principalmente, o narrador valoriza a autenticidade e a espontaneidade dos que têm raízes e as preservam, em evidente demonstração de espírito comunitário. Naquele espaço especial, o contato com os ancestrais gesta alternativos modos de subjetivação e outras formas de sociabilidade:

É um chega ansiado, longamente esperado, e, no fundo, alegre entre o povo ketu e seus eguns, apesar dos temores. Mulheres e homens, filhos de fé, olham reconduzidos para os eguns que baixam. Senzala inteira canta para eles, com harmonia, com uma amizade, como num reencontro. Coisas da boa terra, que é toda pra fora, franca, devocional.

Aqui se gosta da beleza, do ritmo e do que é corporal, musical e vem de dentro (p. 155).

Com a chegada do sol, a substituir "um restinho de lua que já não alumia", tendo os eguns já regressado ao òrun, resta esperar uma nova chance de entrar em contato - festivo - com os representantes da morte, nossa alteridade mais absoluta: "Os eguns vão embora. Só baixarão de novo depois de novas homenagens, holocausto ${ }^{40}$ e pedidos. E, isso, se vierem, lá pelo São João" (p. 155). Agora, necessidades mais primárias podem ser de novo satisfeitas. $\mathrm{O}$ banquete final oferece a todos "arroz, feijão-fradinho com farinha, carne de galinha e de carneiro", depois de uma noite inteira de entrega ao maravilhoso. Identificado - ainda que temporariamente com o vivido, o visitante se imiscui no grupo, relaxando a vigilância sobre hábitos que ali não têm razão de ser: "Como com as mãos, lambuzando as unhas. Igual aos outros" (p. 155). Rastros e sinais do rito invadem o mundo desencantado; contudo, não vige mais o regime do sagrado: "O ojé se cobre ainda de barrete na cabeça e não carrega mais sua vara branca feito cajado. Icham. Não é mais um ojé em dia de festa de eguns, fechada, para os raros, mirongada e bonita. Já não se fala em ioruba" (p. 156).

e Oxaguiã, 2009, p. 349-350). Jorge Varanda também narra a aparição assustadora de um Aparacá (“estranha figura, muda e de movimentos primários”) durante uma cerimônia: “(A) porta se abriu e surgiu flutuante no ar uma tela preta, silenciosa, ameaçando entrar no barracão. 'Babá Aparacá, Babá Aparacá’, gritaram todos apavorados, ao mesmo tempo em que os Ojés e os Omo Inxãs evitavam a entrada daquele Egun diferente” (1985, p. 72-73).

${ }^{40}$ Em seus livros, Santos (2008) e Braga (1995) destacam a centralidade do sacrifício nos ritos de culto aos eguns. 
Significativamente, a última frase do conto é dita não por quem narra, mas - com marcação de discurso direto - pelo homem que "faz carretos na sua kombi de aluguel" e o levará de volta à outra parte do país. A festa será revisitada pelo narrador na hora da escrita. O convite para voltar também ecoando ao leitor, chamado a ciclicamente retornar ao começo, no ritual sempre renovável da releitura: "- Vai e volta, um dia. Que Oxalá se lhe acompanhe" (p. 156).

A visada etnográfica do narrador de João Antônio ilustra, portanto, o alcance (e os limites) da literatura na representação ficcional de aspectos do campo religioso brasileiro, ao combinar o distanciamento que pauta o reconhecimento da diferença com a mobilização de potentes recursos expressivos, os quais documentam e registram, mas também repõem, indefinidamente, o encantamento da descoberta.

Assim seja.

\section{Referências}

ANTÔNIO, João (2001). “Eguns”. In: Abraçado ao meu rancor. São Paulo: Cosac Naify.

AUGRAS, Monique (2008). O duplo e a metamorfose: a identidade mítica em comunidades nagô. 2. ed. Petrópolis: Vozes.

BASTIDE, Roger (2001). O candomblé da Bahia: rito nagô. Trad. Maria Isaura Pereira de Queiroz. São Paulo: Companhia das Letras.

BENJAMIN, Walter (1994). "O narrador: considerações sobre a obra de Nikolai Leskov". In: Obras escolhidas. v. 1. Magia e técnica, arte e política. Trad. Sérgio Paulo Rouanet. 7. ed. São Paulo: Brasiliense.

BOLETIM PROLEITURA (1997), ano 4, n. 17 (dedicado a João Antônio). Assis: Eeditora da Unesp; Maringá: Editora da UEM; Londrina: Editora da UEL.

BRAGA, Júlio (1995). Ancestralidade afro-brasileira: o culto de Babá Egun. 2. ed. Salvador: EDUFBA, Ianamá.

CARNEIRO, Edison (s/d). Candomblés da Bahia. São Paulo: Ediouro.

DEL PRIORE, Mary (2006). "Passagens, rituais e práticas funerárias entre ancestrais africanos: outra lógica sobre a finitude". In: ISAIA, Artur Cesar (org.). Orixás e espíritos: o debate interdisciplinar na pesquisa contemporânea. Uberlândia: EDUFU.

D'OGUN, Guilherme (2004). Iansã do balé: Senhora dos Eguns. 6. ed. Rio de Janeiro: Pallas.

HOLLANDA, Lula Buarque de (2006). Pierre Verger: mensageiro entre dois mundos (DVD). Brasil: Conspiração Filmes,Gegê Produções, GNT Globosat, Europa Filmes.

KILEUY, Odé; OXAGUIÃ, Vera de (2009). O candomblé bem explicado: nações Bantu, Ioruba e Fon. Org. Marcelo Barros. Rio de Janeiro: Pallas. 
LISPECTOR, Clarice (1999). A hora da estrela. Rio de Janeiro: Rocco.

MARTINS, Gilberto Figueiredo (2010). "Ser ou não ser (de santo)? Aspectos do campo religioso afro-brasileiro na peça teatral Balbina de Iansã, de Plínio Marcos". Cerrados, ano 19, n. 29, p. 61-84.

MARTINS, José de Souza (org.) (1983). A morte e os mortos na sociedade brasileira. São Paulo: Hucitec.

MORAES FILHO, Melo (2005). "Um funeral Moçambique em 1830". In: CARNEIRO, Edison (org.). Antologia do negro brasileiro. Rio de Janeiro: Agir (2005). "A festa dos mortos". In: CARNEIRO, Edison (Org.). Antologia do negro brasileiro. Rio de Janeiro: Agir.

MOURA, Carlos E. M. de (Org.) (2011). Culto aos orixás: vodus e ancestrais nas religiões afro-brasileiras. Rio de Janeiro: Pallas.

OLIVEIRA, Ana Maria Domingues de et al. (org.) (2008). Papéis de escritor: leituras sobre João Antônio. Assis: Editora da Unesp.

ORTIZ, Renato (1983). "A morte e sua sombra”. In: MARTINS, José de Souza (Org.). A morte e os mortos na sociedade brasileira. São Paulo: Hucitec.

PRANDI, Reginaldo (2001). Mitologia dos Orixás. São Paulo: Companhia das Letras.

(2005). "Os mortos e os vivos". In: Segredos guardados: Orixás na alma brasileira. São Paulo: Companhia das Letras.

QUEIROZ JUNIOR, Teófilo de (1983). “Dos mortos e sua volta”. In: MARTINS, José de Souza (org.). A morte e os mortos na sociedade brasileira. São Paulo: Hucitec.

RIBEIRO, José (s/d). As festas dos eguns. 2. ed. Rio de Janeiro: Eco.

RIO, João do (2006). "A casa das almas". In: As religiões do Rio. Rio de Janeiro: José Olympio.

SANTOS, Juana Elbein dos (2008). Os Nagô e a morte. 13. ed. Trad. UFBA. Petrópolis: Vozes.

SANTOS, J. E. dos; SANTOS, Deoscóredes M. dos (2011). “O culto dos ancestrais na Bahia: o culto dos Eguns". In: MOURA, Carlos E. M. de (Org.). Culto aos Orixás: vodus e ancestrais nas religiões afro-brasileiras. Rio de Janeiro: Pallas.

SELJAN, Zora (1978). 3 mulheres de Xangô e outras peças afro-brasileiras. 2. ed. São Paulo, Ibrasa; Brasília: INL.

VARANDA, Jorge Alberto (1985?). Os eguns do candomblé. Rio de Janeiro: Eco. ZIEGLER, Jean (1977). “Os espíritos de Itaparica”. In: Os vivos e a morte. Trad. Áurea Weissenberg. Rio de Janeiro: Zahar.

Recebido em novembro de 2011.

Aprovado em março de 2012. 


\section{resumolabstract}

Os convivas da morte no banquete das almas: presença de eguns em um conto de João Antônio

Gilberto Figueiredo Martins

A literatura escrita tem sido um espaço privilegiado para a representação e, consequentemente, para o registro e divulgação dos valores e costumes de variados grupos e segmentos sociais. No conto analisado neste ensaio - "Eguns" -, o escritor paulistano João Antônio (1937-1996) traz um narrador que descreve com detalhes uma rara festa religiosa ocorrida na Bahia, destinada ao culto dos ancestrais. Contemplativo e respeitoso, limita-se a contar o que a tradição religiosa permite. O contato com a alteridade ganha foros de rito iniciático e a experiência - em sentido forte - é transferida ao leitor.

Palavras-chave: João Antônio, identidade afro-brasileira, conto brasileiro contemporâneo, religião e literatura.

Os convivas da morte no banquete das almas: presence of eguns in a João Antônio's short story

Gilberto Figueiredo Martins

Written literature has become a privileged space for performance and, consequently, for recording and fostering of values and practices of various groups and social segments. In the short story analyzed in this essay - "Eguns" - João Antônio (1937-1996), a writer from São Paulo, presents a narrator who describes in detail an unusual religious celebration held in Bahia, meant for the cult of ancestors. Contemplative and respectful, it sticks to tell what is allowed by the religious tradition. Contact with alterity achieves the status of initiation rite and the experience - in a strong sense - is transferred to the reader.

Keywords: João Antônio, Afro-Brazilian identity, contemporary Brazilian shortstory, religion and literature. 